\title{
DEVELOPING ENGLISH MATERIALS FOR STUDENTS WITH VISUAL IMPAIRMENT AT LANGUAGE DEVELOPMENT CENTER (P2B) STATE ISLAMIC UNIVERSITY (UIN) SUNAN KALIJAGA
}

\author{
Dharmasanti Rawidya Putri \\ Universitas Islam Indonesia, Jalan Kaliurang Km 14, Yogyakarta, Indonesia \\ Email: 093120405@uii.ac.id \\ DOI: 10.29313 /tjpi.v6i1.2522 \\ Accepted: May 18th, 2017. Approved: July 20th, 2017. Published: July 20th, 2017
}

\begin{abstract}
The research starts from the necessity of the visual impairment students to have their own and specific media to learn due to their disability condition. The research is conducted in State Islamic University Sunan Kalijaga Yogyakarta as one of the inclusive university in Indonesia. The research involves four visual impairment students who learn English subject together with another non-visual impairment student in Class P academic year 2014/2015. The development of the English materials involves the conduct of need analysis to know the need of the topic of English subject. This study belongs to Research and Development (R\&D). in which educational $\mathrm{R} \& \mathrm{D}$ is a process used to develop and validate educational products. The result of the study is the need analysis itself and the development of the English material based on the need analysis.
\end{abstract}

Keywords: Development of Materials, Need Analysis, and Inclusive Education.

\begin{abstract}
ABSTRAK
Penelitian ini berawal dari kebutuhan mahasiswa tuna netra tersebut untuk memiliki media pembelajaran Bahasa Inggris sendiri yang sesuai dengan kondisi disabilitas mereka. Penelitian ini dilakukan di Universitas Islam Negeri Sunan Kalijaga Yogyakarta yang merupakan universitas inklusi di Yogyakarta. Penelitiuan ini melibatkan empat mahasiswa tuna netra yang belajar Bahasa Inggris bersama-sama dengan mahasiswa non disabilitas di Kelas P tabun ajaran 2014/2015. Pengembangan modul Bahasa Inggris ini menggunakan analisis kebutuhan untuk. mengetabui topic atau tema apa saja yang dibutubkan mahasiswa tuna netra dalam pembelajaran Babasa Inggris. Penelitian ini termasuk dalam bidang Pengembangan dan Penelitian untuk mengembangkan dan memvalidasi sebuah produk pendidikan. Hasil penelitian berupa analisis kebutuhan dan modul pembelajaran Babasa Inggris untuk mahasiswa tuna netra di Universitas Islam Negeri Sunan Kalijaga Yogyakarta.
\end{abstract}

Kata Kunci: Pengembangan Modul, Analisis Kebutuban, Pendidikan Inklusi. 


\section{INTRODUCTION}

Islamic State University (UIN) Sunan Kalijaga Yogyakarta is a foster university which tries to be the place for the disabled students pursuing their higher degree. It applies inclusive education in almost all of its faculties and departments. Hence, numerous adaptive services are provided to students with a disability as well as its Centre for Disability Services (Pusat Layanan Difabel; PLD). It also advocates overcoming all types of discrimination in the university, especially regarding accessibility. It provides many adaptive services such as talking computer, electronic book (eBook) production, buddy system, reading service, etc. The services are not exclusively for the needs of students with visual impairment; however, students with other types of disabilities such as individuals with a mobility disability, hearing impairment, and autism have registered to this university. Being the inclusion university is not easy. At least the university should handle themselves with innovations for visually impaired students to follow the process of learning well. Also, the university also should be able to provide awareness to all academicians that undergraduate students can also follow the blind education in public universities. Restructuring the curriculum, teaching methods, teaching aids, teacher competency, evaluation, and academic services must be arranged in such a way that would take time and a substantial investment. Related to the inclusive condition, the students are supposed to mingle each other. It means that all the students whether they are able or disable ones should sit and learn the subjects together. It does happen since the government guarantees that everyone has a right to have an education. "Education is a basic right for all citizens without exception." That statement can be found in the 1945 Constitution of Indonesia, article 31(1), which states that every citizen has the right to get a proper education and teaching access. It means that it includes everyone, no matter their cultures, religions, wealth, ability, and ethnicity.

The National Educational Act number 20, 2003 article 3 about National Education System or Sisdiknas (Sistem Pendidikan Nasional) mandates that national education system in Indonesia serves to develop students' skill, character, and civilization in the context of improving the intelligence of the nation, developing the potential of students in order to produce religious people who are noble, healthy, knowledgeable, skilled, creative, independent, and democratic and responsible citizen of Indonesia. In practice, the actual condition shows that several problems still arose in the education system in Indonesia. It can be seen from some difficulties such as low quality of output students, lack of professional teachers, expensive education fee, or the chaos of education policies. As a result, Indonesia is getting more unexpectedly offended. Without a significant amendment of the policies, it will be difficult for Indonesia to get out from recent educational problems to survive in the global competition.

To go further, it is important then to take a look at Law no. 20 of 2003, on National Education System, chapter 4, article 5, paragraph 1 and 2 states clearly that every citizen has the same right and opportunity to acquire qualified education. Besides, citizens who have special needs such as physical, emotional, intellectual and social disabilities are entitled to obtain a special education. It means that people with disabilities and impairments at the same time have the same right as other normal people to study through inclusive education.

The right to get an education for those special need citizens is then strengthened by The Ministry of Culture and Education Regulation of Republic of Indonesia no 462014 on Chapter II Article 2 of the Objective stating that higher education aims the inclusive education for disabled people to: 
(1) Widen the access and opportunity for the disable inhabitants to get higher education; (2) Widen the access and opportunity for the disable inhabitants who have higher intelligence and special talent to get higher education; (3) Provide special access and treatment for disabling inhabitants to join educational and other related activities at higher education to achieve optimal achievement; and (4) Provide special access, and treatment for higher intelligence and special talented disable inhabitants to join educational and other related activities at higher education to achieve optimal achievement.

In article 5 the ministry regulation continues by giving a set of rules of the upper schools providing facility and infrastructure for these disabled citizens. They are some important rules, and the seventh rule stating that the disables has right to pursue higher education by using special media and learning resources such as talking book, Braille book, scanner and Braille computer, electronic book and website. In Islam, one of the distinctive features of this religion is its emphasis on knowledge. The Holy Qur'an and the Islamic Tradition (Sunnah) invite Muslims to seek and acquire knowledge, wisdom, and understanding of Deen and to hold men of knowledge in high esteem. The first few verses of Holy Qur'an that were revealed to our Holy Prophet Mohammed (践-Sallallaho Alaihi Wa'Sallam): "Read in the name of your Lord who created." "Created man, out of a (mere) clot of congealed blood." "Read, and your Lord is the most Generous." "Who taught by the pen." "Taught man that which he knew not." (Holy Qur'an 96:1-5). Hence, it is a beautiful prayer for every Muslim to ask always: "O my Lord! Increase me in knowledge." (Quran 20:114). The only limit set to the acquisition of knowledge in Islam is that Muslims should seek useful knowledge. Our great Prophet Alaihi Wa'Sallam) is reported as having said: "My Lord, save me from the useless knowledge." Useless means that is not helpful towards anything. Based on $\mathrm{Al}$ Quran, Al Hadits and supported by the government's rule, it is clear that education is a right for everyone, who are disabled or able. This research focuses on the study on developing English materials for students with visual impairment at Language Development Center (P2B) in Islamic State University (UIN) Sunan Kalijaga. The generalization of the research finding only applies to the subjects under investigation and those who share the similar characteristics of the subject of the study. In line with the previous background, the researcher will focus on the study on developing English materials in teaching English to students with visual impairment at Islamic State University (UIN) Sunan Kalijaga.

\section{THEORETICAL REVIEW}

\section{English Language Teaching}

The way of communication is called language; it means that by using the language people can communicate their ideas to the other or to interact with others. H. Douglas Brown (2000:5) states that language is a system of arbitrary conventionalized vocal, written or gestural symbols that enable members of given community to communicate intelligibly with one another. Language is systematic. Language is a set of arbitrary symbols. The symbols are primarily vocal, but may also be visual. The symbols have conventionalized meanings to which they refer. Language is used for communication and operates in a speech community or culture. It is essentially human, although possibly not limited to human. All people acquire language in much the same way, both language and languages learning have universal characteristics $(\mathrm{H}$. Douglas Brown, 2000:7).

English is considered as an International Language. Thereby, people who come from diverse backgrounds geography, religion and culture have had an 
agreed media to communicate with each other, namely English. There is an important key that determines the success of a teacher in teaching foreign language in the classroom. That is choosing the most suitable approaches, methods, procedures, and techniques. An approach was a set of assumptions dealing with the nature of language, learning, and teaching. The approach is theoretically well-informed positions and beliefs about the nature of language, the nature of language learning and the applicability of both to the pedagogical setting (H. Douglas Brown, 2000: 14). Brown also stated that method was described as an overall plan for systematic presentation of language based upon a selected approach. The method is a generalized set of classroom specifications for accomplishing linguistic objectives. Methods tend to be concerned primarily with the teacher and student roles and behaviors and secondarily with features as linguistic and subject-matter objectives, sequencing materials. They are almost always thought of as being broadly applicable to various audiences in various contexts. The technique is the specific activities manifested in the classroom.

\section{English Language Learning}

When people do learning, there will be a change in their behavior. This statement is in line with the behaviorist theory that defines learning as a habit formation. It is a mechanical process of habit formation and proceeds using the frequent reinforcement of a stimulus- response sequence (Hutchinson and Waters, 1987).

Chomsky (1964) in Hutchinson and Waters (1987) told the behaviorist theory of how the mind was able to transfer what was learned in one stimulus-response sequence to other situations. Chomsky concluded that thinking must be rule-governed, a finite and fairly small. Set of rules enables the mind to deal with the potentially infinite range of experiences it may encounter. Learning not only consists of forming habits but acquiring rules. A process in which individual experiences are used by the mind to formulate a hypothesis. This is what is called mentalist theory.

In learning English as a second language or foreign language, two determinant factors are initiating the success of second language learning. The factors include external factors and internal factors (Rod Ellis, 2003: 67). External factors include physicals and social environment or demographic variables, cultural setting, formal teaching and the like. The internal factors, on the other hand, embody learner physical condition, aptitude, attitude toward second language, motivation, intelligence, learning styles, learning strategies and others. Of the internal factors, learning strategies are believed to be a determinant factor for the success of second or foreign language teaching and learning because learning strategies are concerned with practical and operational efforts of how to handle the task. Added to the learning strategies establish independent learner learning that applies to deal with any task that they face. Learning strategies are very important for second language learners as learning strategies empower learners to activate their learning management.

\section{Materials Development: The Nature of Materials}

The material is everything which is used to help to teach language to the students. Materials can be in the form of a textbook, a workbook, a cassette, a CD, a video, a photocopied handout, a newspaper, or even a paragraph written on a whiteboard. In other words, materials can be everything which is deliberately used to increase students' knowledge and experience of the language (Tomlinson, 1988). Tomlinson (1988) also referred that materials development refers to anything done by writers or teachers or students to provide sources of language input which maximize 
the supplying of information and experience of language in ways designing to promote language learning.

\section{The Role of Instructional Materials}

There are many opinions about the role of instructional materials in the language classroom. Crawford in Richards and Renandya (2002) stated that some experts criticized the public materials. They claim that textbooks reduce the teacher's role to one of managing or overseeing preplanned events, textbooks are for poor teachers without imagination, and so on. Then Crawford stated that Alwright (1981) suggested that there are two key possibilities about the role of instructional materials:

\section{Visual Impairment Students}

Students with visual impairment are a group of students who have visual problems. Commonly, people could say this condition as blind. There are two main categories of visual impairments, i.e.: low vision and blind. According to Susan Carney, et.al (2001: 7), most students with visual impairments have low vision. These students should be encouraged to use their residual (remaining) vision, when appropriate, using the necessary optical aids and adaptations. On the other hand, blind students range from being total without sight to unreliable vision and primary reliance on other senses. A person with blindness usually uses Braille as reading and writing medium

Meanwhile, WHO divided four levels of visual function, according to the International Classification of Diseases -10 (Update and Revision 2006): (1) normal vision; (2) moderate visual impairment; (3) severe visual impairment and (4) blindness. Moderate visual impairment combined with severe visual impairment are grouped under the term "low vision": low vision taken together with blindness represents all visual impairment. Similarly, Manal (2012: 1) also stated that there is four categories of visual impairment: (1) partially sighted, (2) low vision, (3) legally blind and (4) blind. Partially sighted means that the person has some difficulties in seeing and reading information, and requires special assistance with learning and reading. Low vision indicates a more serious visual impairment, where reading at normal distances is not possible. People with low vision have to use supportive tools to read and see in their environments. They may even learn through the use of Braille. Legally blind refers to a vision less than 20/200 and a limited range of vision. People who are legally blind cannot see things clearly, whether it is near or far. Blind means that the individual has no vision at all. Their eyes are not able to process images, and they learn through nonvisual resources, including Braille. According to WHO (2012), globally the major causes of visual impairment are uncorrected refractive errors (myopia, hyperopia or astigmatism) (43\%), cataract, $(33 \%)$ and glaucoma $(2 \%)$. Besides, the age at which they become impairment visually also affects their needs. Students who were born visual impaired has different needs with students who lose their sight during their childhood or teenage.

Considering that each student with visual impairment has different learning needs, therefore, it is necessary for lecturers to know the types and causes experienced by the student with visual impairment at the beginning of the instructional process. So, the lecturers can choose an appropriate instructional design in their classrooms.

\section{English Learning for Students with Visual Impairment}

A few years ago, students with visual impairments were placed in a special school for blind students and did not get any opportunity to attain higher education. Now, they can study together with sighted or normal students in regular school or university. Placing students with special 
needs in the regular classroom is called inclusive education.

Dealing with students with visual impairments in our classroom is not a big matter as long as the lecturers know how to communicate with them. The lecturer and other students should understand the most appropriate ways to accommodate students with visual impairments in the classroom as well as in examination.

According to the Center for Disability Services (Pusat Layanan Difabel) of State Islamic University (UIN) Sunan Kalijaga, there are several best practices in adaptive learning that can be integrated in learning process, such as: (1) student's physical condition; (2) learning objective; (3) learning strategy and (4) learning evaluation.

The first aspect is students' physical condition. The classroom should be set based on their condition. Appropriate seating is important for a visually impaired student; since the student cannot see visual cues, he or she needs to be seated in a position to receive verbal cues. The best seat for him or she is close to the teacher so they can listen to the lecture. The lecturers need to try to speak directly to the class, remember that turning our head away can muffle sound because body language and gestures cannot be seen. Besides, it is necessary to control background noise since it will distract visually impaired student's attention.

The second aspect is learning objective. The most potential English skill that they can master well is listening and speaking because a student with vision impairment has a sight problem, not hearing loss. Use their ability to deliver most of the content. Use general vocabularies to explain the lesson. Do not hesitate to use words such as look or see; students with vision impairments use these terms too.

This is in line with Rofah, et al. (2010: 42) that states that lecturer should accommodate learning needs of students with visual impairment who use different aids suitable for their disabilities and resources that they have. She said that lecturers should give a soft copy of teaching material to students with visual impairment, give reference lists beforehand because they need longer time to access information. The lecturer should narrate visual educational materials and avoid too much visual content in teaching material. Also, the lecturer should consider outdoor activity (field trip, interview) if it is regarded as a problem for students with visual impairment to deal with.

The third aspect is methods. In doing the learning process, lecturers can integrate some approaches and media. The lecturers can use various media, especially audio media (audio recording, speech or lecture) to support the learning process. Lecturers also can ask students about learning aids that they may need during the process. Moreover, arrange computer lab accessibility with IT technician and disable center - (multimedia-based learning). Allow the student to work with a partner or allow a volunteer in the class to support the student (teamwork). Make sure the materials are organized and easily accessed by the student. Enable the student to record result verbally instead of writing them. Verbalize every writing on the whiteboard and spell every technical term.

Rofah, et al. (2010b: 41) also said that learning method for students with visual impairment should be cooperative learning instead of competitive learning. Competitive learning will make students with visual impairment lose they're self-confident and are possibly left behind by the student without visual impairment.

The fourth, adaptation in assessment and examination for students with visual impairment must be considered, too. Evaluation and review are instrumental for the teacher to evaluate and find out students' development and achievement. There are some adaptations, as follow: (a) Choose appropriate test type. Lecturers can choose test type such as oral examination by using an interview or listening test by using audio. Besides, it is better to make close books 
examination instead of an open book because it will be difficult for students with visual impairment to access their literature;(b) Tests can be administered by having the questions read to the students by a volunteer or assistant. The assistant will read and write for the blind students. However, in English exam, it will be problematic when the assistant does not have good proficiency in English. Both the students and the assistant will get into trouble;(c) if the students can access a computer with JAWS, they can get an independent test. The lecturer just needs to give the exam in soft files to the students; then they can 'read' it independently on their computer; (d) Reproduce exams in largel. print if the student has low vision. (e) Allow2. extra time (about 20-50\% longer) for test taking in a separate and quiet setting.

\section{RESEARCH METHODOLOGY}

This study belongs to Research and Development (R\&D). According to Gall, Gall, and Borg (2003), educational R\&D is a process used to develop and validate educational products. The steps of this process are usually referred to as the $\mathrm{R}$ and $\mathrm{D}$ cycle, which consists of studying research findings pertinent to the product to be developed, developing the product based on these findings, field testing in the setting where it will be used eventually, and revising it to correct the deficiencies found in the field-testing stage. Further, the steps in R3. and $\mathrm{D}$ cycle can be several times repeated4. until the field-test data indicate that the product meets its behaviorally defined objectives. On the other hand, the aim of the educational research is not to develop products, but truly to discover new knowledge (through basic research) or to answer specific questions about practical problems (through applied research). Moreover, an industry-based development is another name for the $\mathrm{R}$ and $\mathrm{D}$ research model in which the findings of the research are used to design new products and procedures, the products and procedures then use systematically field-tasted, evaluated, and refined until they met specified criteria of effectiveness, quality or standards.

\section{DISCUSSION}

To focus on the development of the English model, the researcher conducted need analysis to find out the interest of the students toward English topic or theme. The result of the need analysis would be used thus to develop English material for the visual impairment students.

\section{Need Analysis}

Need analysis was conducted to find out the student's needs. It was done by distributing questionnaires to the visual impairment students at Center of Language Islamic State University (UIN) Sunan Kalijaga Yogyakarta as the respondent on October 23, 2014. There is a kind of information that the researcher needs to gather from an analysis of target needs. In this research, the outline of a need analysis framework based on Hutchinson \& Water (1987: 59). The results of need analysis by distributing questionnaires to the visual impairment students at Center of Language Islamic State University (UIN) Sunan Kalijaga Yogyakarta are as follow.

\section{Descriptions of the Students}

English is a compulsory subject in Center of Language Islamic State University (UIN) Sunan Kalijaga Yogyakarta. It is taught in the first semester for all the students without exception. The respondents for the questionnaires here were the students with a disability in seeing or the visual impaired ones. There were four students from Dakwah Faculty at Center of Language Islamic State University (UIN) Sunan Kalijaga Yogyakarta, Class P. They were all male students aged 19 years old. 


\section{The Result of the Need Analysis}

In conducting the need analysis, the researcher applied Hutchinson \& Waters (1987: 59-63), and it was developed based on the context of the research subject. The results of the need analysis revealed what kind of materials that the students wished to have. It also included the components of the materials such as inputs of the materials that the students were faced mostly and the activities that the students needed to prepare for their future job. There were 25 multiplechoice questions in need analysis questionnaire. The result of the need analysis was described as follows.

The elaboration of the product of student need analysis gave a clear description that the students wanted to learn English in four skills but focused on developing their speaking skill including vocabulary and grammar as other main aspects. From the need analysis questionnaire, all the visual impairment students $(100 \%)$ opted the listening materials for more than 4 minutes. It did not come as a surprise since they could not see the material, and they preferred to learn the materials from the audio instead of the visual. Moreover, it is also informed that the visual impairment students chose to get the input of text form less than 50 words shown by the percentage of $50 \%$ from all the students, and the rest $50 \%$ chose to have text input between 50-100 words. Their preference to opt the input of text for less than 100 words is caused by their inability to read the reading text so that the visual impairment students feel comfortable enough to choose the input of text for maximum 100 words.

It was clear enough from the questionnaire that the visual impairment students like mostly $(50 \%)$ to have the topic which is related to dreams. The result of the students' need analysis on the learner's input can bee is seen in the appendix. The learning needs were also attained from the questionnaire. There are the needs which were determined by what the learners wanted. These needs were closely related to the procedure, setting, learners' role, and teachers' role which conveyed the "how-tolearn" matters in the teaching and learning process. These are the results of the questionnaire in the form of some tables. Based on the learning need in speaking activity, the students are most likely (50\%) to have activities on speaking for telling daily activities. For daily activities they prefer to have the speaking material telling their friends about their habitual action in their everyday life such as going to college, taking a shower, watching television, or accomplishing their prays to Allah.

The questionnaire on student's need analysis showed the information that related to the learning needs in pronunciation activities, most of the visual impairment students $(75 \%)$ would like to have the activities of identifying the sound of English words correctly like what was stated exactly in the dictionary. To reinforce speaking skill related to the reading activities, as many as three students out of 4 students $(75 \%)$ mentioned reading a text and determining the detail information as the main reading activities which can strengthen their speaking skill as well.

Another one student (25\%) considered that reading a certain text and answer the following questions will be best to reinforce their speaking skill after all. In vocabulary activities, the table from the need analysis illustrated that one student $(25 \%)$ would like to have matching activities to reinforce their speaking skill in vocabulary activities, and two students (50\%) commented that they are most likely to have to apply words in the context. Finally, the rest of the student for $25 \%$ chose to identify the part of speech as the vocabulary activities to reinforce the speaking skill.

In writing activities to reinforce the speaking skill, one student $(25 \%)$ out of 4 students commented that he preferred to have writing activities in arranging jumbled sentences into a text. Another one (25\%) would like to have writing exercise by paying 
attention to the punctuations, and the rest of other four students $(50 \%)$ gave comment to have writing activities in a dialogue.

In grammar activities in order to reinforce the visual impairment students in speaking skill, as many as 3 students out of $4(75 \%)$ preferred to practice speaking and writing by paying attention to the tenses while another 1 student (25\%) would like to do exercise according to the grammar that is being learnt.

For the teacher's role, still in the learning needs, 1 visual impairment student $(25 \%)$ would like to comment that the 5 . teacher mostly liked to behave as an instructor in the class while another 16. student $(25 \%)$ stated clearly that he would like to have the teacher's role as an observer and participant. The table of need analysis also informed that one student $(25 \%)$ chose the teacher's role as the one who acted as facilitator, and the rest on the student (25\%) opted the teacher's role as the communicative one.

Moving to the learner's role, Table 4.10 illustrated that two out of four of the students $(50 \%)$ gave a comment that they should behave as the active participants in the teaching and learning process of English class. Another one student (25\%) stated that he would perform the learner's role as listeners and performers in the class. As the final result, one of the students (25\%) commented that he chose to be participants who listen and do teacher's instruction on the Learner's Role.

In the setting table, it was informed that one student $(25 \%)$ chose to have set in the classroom with varied seating arrangement which meant that he preferred to sit differently every time the class started. In other words, he would like to have freedom in picking the seat as he wished. Further, for the rest of the students, three students $(75 \%)$ opted to have the setting as sometimes outside the classroom which was still in the University area. It meant that the visual impairment students liked to have different kinds of environment whenever they wanted to study English. Even though they were not able to see the view and the setting, but they could feel the different ambiance surrounding them. To go further, in the setting for the visual impairment students, all of them agreed that they did English teaching and learning in a group discussion rather than individually or pair discussion. At last result, 2 of the students $(50 \%)$ prefer to do $15-20$ tasks, while on the other hand the rest of the students (50\%) ask for 20-50 tasks in a unit.

\section{The Development of the English Material}

Based on the result of the need analysis distributed to the visual impairment students, the researcher then developed the material which was suitable with the interest of the students. Besides concerning the syllabus, the units were developed by regarding the results of the need analysis. Based on the syllabus, twelve materials were developed into sixteen units of materials. The sixteen materials were represented by the four units that were developed as samples to get the best design. To start with, here is the outline description of the general design of each unit.

Unit Title consists of Task 1 Simple Present Tense which involves "Audio Listening material" and "Brainstorming questions." There is Task 2Let's Do, involves "Audio Listening material" and "Discussion of language function," "Comprehension checking task," "Oral exercise," and "Checking oral task." In Task 3- Grammar Point, there are "Audio Listening material," "Example of sentences," "Leading questions," "Discussion of grammar" and "Comprehension checking task." The further task is Task 4- Writing consists of "Audio material example of writing," "Exercise of the writing sentences and comprehension checking," "Writing exercise," and "Free activity derived from 
the writing exercises." The last task is "Self Evaluation" activity.

The units commonly consisted of the phases mentioned above, and each unit began with a title which was chosen from the topic or theme related to the need analysis and the learning goal based on the syllabus. Then it had a warm up in the form of audio material which led the students to the goal of learning in each unit. The next phase was the activities. In this stage, students were given some activities that prompted their macro skills (reading, listening, writing and speaking) and micro skills (vocabulary, pronunciation, and grammar)) as well as their background knowledge about the topic they were learning. A self-evaluation activity ends the unit.

\section{CONCLUSIONS}

Based on the research findings, it can be concluded that effective English learning material tasks for visual impairment university students of Islamic State University (UIN) Sunan Kalijaga Yogyakarta have the following characteristics. (1) The tasks aim at developing visual impairment students' English macro skills namely listening, writing, and speaking and visual impairment students' English micro skills such as vocabulary, grammar and pronunciation as well. (2) The tasks are divided into four main stages for each unit. They are introduction stage, and the main lesson consists of speaking tasks; grammar; vocabulary and pronunciation; and listening and writing tasks. (3) The effective unit design has the following components: a). Unit Title: The title is chosen from the topic or theme related to the need analysis and the learning goal based on the syllabus; b)Task 1- Warm- Up This warm up stage leads the students to the goal of learning in each task. It has brainstorming questions like the questions leading the students about the material they would like to study. The leading questions also lead the students to discuss each other and share knowledge in a group work in order to get the idea toward or recall students' background knowledge about the topic discussion; c) Task 2- Let's Do: This task aims to activate the students' brain about the topic introduced in Task 1. The task-focused mainly on English daily life expression; d) Task 4- Writing: Each unit is ended by writing stage where the students are required to write some sentences or short paragraph related to the topic they have just discussed or learned. This stage will enrich the students to have more examples of English inputs in the form of writing. The activity is derived from the listening material the student has just listened to. The questions of this phase are taken directly from the listening materials. The writing task is also included a freer activity where the students are asked to produce their language in the form of individual work, pair work, or a group work.

\section{REFERENCES}

Brown, H. Douglas. (2000). Teaching by Principles. An Interactive Approach to Language Pedagogy. New York: Pearson Education.

Carney, Susan et.al. (2001). Teaching Students with Visual Impairments. Retrieved from (http://www.education.gov.sk.ca/vi sion), on 01 May 2013

Crawford, J. (2002). The Role of the Materials in the Language Classroom: Finding the Balance in Richards, J. C. And Renandya, W. A. (eds) Methodology in Language Teaching, an Anthology of Current Practice. Cambridge: Cambridge University Press

Ellis, Rod. (2003). P.67 Task-Based Language Learning and Teaching. New York. Oxford University Press.

Gall, M.D., Gall, J.P., and Borg, W. R. (2003). Educational Research: An Introduction. 7 th Edition. New York: Pearson Education

Hutchinson, and Water. (1987). English for Specific Purposes. Cambridge: Cambridge University Press 
Richards, J. C. \& Willy A. Renandya. (2002). Methodology in Language Teaching: An Anthology of Current Practice. USA: Cambridge University Press

Rofah, Andayani and Muhrisun. (2010). P.41 Membangun Kampus Inklusif. Best Practices Pengorganisasian Unit Layanan Difabel. Yogyakarta: Pusat Studi Lananan Difabel (PSLD) UIN Sunan Kalijaga

Tomlinson, Brian. (1988). Materials Development in Language Teaching. Cambridge: Cambridge University Press. 